\title{
Differences in Teachers' Knowledge of Language
}

\author{
Laureen J. Mclntyre and Laurie-ann M. Hellsten \\ University Saskatchewan
}

\begin{abstract}
Teachers need to expand their understanding of language in order to meet the diverse language and literacy needs of their students. Students may demonstrate deficits in the domains of language form (phonology, morphology, syntax), content (semantics), and use (pragmatics). However, existing studies have only investigated teachers' knowledge of language form. Therefore, this study investigated 236 preservice and inservice teachers' knowledge of language form, content, and use as well as the teacher characteristics that may influence this knowledge. Both preservice and inservice teachers were found to have low levels of language knowledge. Experienced teachers, inservice teachers, and inservice teachers taking graduate level courses at a university tended to perform better than preservice teachers with no teaching experience on all three subscales. These findings have implications for teacher training programs and for professionals providing support services to classroom teachers.
\end{abstract}

There is an established foundation of research demonstrating that poor readers may exhibit a variety of language deficits (e.g., Adams, 1990; Hogan, Catts, \& Little, 2005; Stanovich, 1988; Stanovich \& Siegel, 1994; Swan \& Goswami, 1997), and children with language difficulties may have difficulty reading later in life (e.g., Catts, Adlof, \& Weismer, 2006; Catts, Fey, Zhang, \& Tomblin, 1999; Catts \& Kamhi, 1999; Stothard, Snowling, Bishop, Chipchase, \& Kaplan, 1998). These language difficulties include phonological processing deficits (i.e., deficits in phonological awareness, phonological retrieval, and/or phonological memory; Catts, 1996; Catts \& Kamhi, 1999; Torgesen, Wagner, \& Rashotte, 1994), competence in semantics (i.e., lexical processing; Roth, Speece, \& Cooper, 2002; Roth \& Spekman, 1991; Snow \& Burns, 1998), and pragmatics (i.e., communication intentions, conversational skills, and/or narrative skills; Adams \& Bishop, 1989; Feagans \& Short, 1984; Klecan-Aker \& Swank, 1987, 1988). Most of these children will receive reading instruction in inclusive classrooms alongside an already diverse group of typically achieving students. It seems reasonable to expect that teachers' abilities to 
provide adequate reading instruction in such environments depend on their knowledge of language.

Existing research on teachers' knowledge of language is limited and has focused on their knowledge of language form - phonology, morphology, and syntax (Mather, Bos, \& Babur, 2001; McCutchen et al., 2002; Moats, 1994). For example, Moats (1994) was interested in assessing "the specificity and depth of teachers' knowledge [of language form]" (p. 89). Participants were administered one of two surveys that assessed their abilities: to give definitions for linguistic terms; to find and/or come up with examples of phonic, syllabic, and morphemic units; and to analyze and segment words into speech sounds, syllables, and morphemes. Moats found that participants demonstrated difficulty with "the very skills that are needed for direct, language-focused reading instruction, such as the ability to count phonemes and to identify phonic relationships" (p. 91). Teachers need to expand their understanding of spoken and written language form so they are able to teach language form to beginning readers and individuals with reading/spelling disabilities (Moats, 1994). This knowledge of language is important since “teachers' content [or subject] knowledge is critical to successful instruction because they can then choose what to teach, when, how, and to whom" (Moats, 1994, p. 95).

Mather et al. (2001) also considered teachers' knowledge of language form. These researchers set out to investigate the knowledge and perceptions of preservice and inservice educators relating to early literacy. Researchers utilized a knowledge assessment, The Teacher Knowledge Assessment: Structure of Language, which was adapted from Lerner (1997), Moats (1994), and Rath (1994). Mather et al. (2001) found that "inservice teachers were more knowledgeable about the structure of language than preservice teachers. Neither group, however, obtained high scores on the assessment" (p. 476). Similar to Moats (1994), Mather et al. (2001) concluded that teachers need to expand their understanding of spoken and written language structure.

Teachers have demonstrated areas of need in their understanding of language structure or form. In McCutchen et al.'s (2002) study, researchers first assessed teachers' knowledge of language form then investigated whether this knowledge could be improved with training. Several areas of teacher knowledge were assessed: teachers' general knowledge; their knowledge and beliefs about teaching reading; and their knowledge of language form, using the Informal Survey of Linguistic Knowledge (Moats, 1994; Moats \& Lyon, 1996). The initial assessment of teachers' general knowledge and their knowledge of language in both the experimental and control groups found that "despite their high knowledge of the world in general, these teachers were not very knowledgeable about English phonology and orthography as measured by the Moats survey" (McCutchen et al., 2002, p. 75). The results of the study revealed that teachers' knowledge of phonological awareness and their use of this knowledge to change their classroom practice were deepened following intervention; these changes in turn improved student learning (McCutchen et al., 2002). This study linked increased knowledge of language form to improved student reading outcomes. These findings led McCutchen and her colleagues to conclude that "when effective practice is in the hands (and heads) of teachers, who work on the educational front lines, we may begin to hope for progress in the only reading war that really matters - the one against reading and writing disability" (McCutchen et al., 2002, p. 82).

Teachers need to expand their understanding of language form in order to meet the diverse language and literacy needs of their students. However, the difficulties students experience with language are not always related to the domain of language form. Students may also demonstrate deficits relating to the domains of language content (semantics; e.g., Roth et al., 2002; 
Roth \& Spekman, 1991; Snow \& Burns, 1998) and language use (pragmatics; e.g., Adams \& Bishop, 1989; Feagans \& Short, 1984; Klecan-Aker \& Swank, 1987, 1988). Although studies have investigated teachers' knowledge of language form, studies have not assessed teachers' knowledge of semantics and pragmatics.

There is clearly a need to investigate what teachers know about language form, content, and use. Information on the level of oral language knowledge of teachers, and the teacher characteristics related to this knowledge, would be particularly beneficial to teacher education programs training preservice teachers, and professionals providing supportive services to classroom teachers. For example, speech-language pathologists (SLPs) are typically expected to provide support to the classroom teacher in order to meet the needs of students with languagebased learning difficulties. As the American Speech-Language-Hearing Association (2001) stated:

speech-language pathologists (SLPs) play a critical and direct role in the development of literacy for children and adolescents with communication disorders, including those with severe or multiple disabilities. SLPs also make a contribution to the literacy efforts of a school district or community on behalf of other children and adolescents. (p. 69)

Teachers actively work with and adapt the classroom curriculum and bring this knowledge and experience to their collaborative partnerships. However, teachers may need to expand their understanding of language form, content, and use in order to meet the needs of students experiencing diverse language difficulties. Providing inservice opportunities and collaborative consultations that target classroom teachers' current level of language knowledge could only benefit students experiencing language and/or literacy difficulties in our classrooms. Therefore, the purpose of this study was to explore differences in teachers' knowledge of language form, content, and use.

\section{Hypotheses}

Previous research in the area of teachers' knowledge of language has found that teachers need to expand their knowledge of language form (Mather et al., 2001; McCutchen et al., 2002; Moats, 1994). Therefore, one would expect teachers to have low levels of language knowledge in the domain of language form, particularly on scales that contain aspects of the informal surveys used in previous research studies (e.g., Moats, 1994). If teachers need to expand their understanding of the domain of language form, there is no existing rationale for why the pattern would not be similar in the other domains of language. Therefore, it was hypothesized that teachers would also have low levels of language knowledge in the domains of language content and language use.

One expects a person's knowledge base to expand as he/she gains more work experience. In the case of a classroom teacher, as a teacher gains more experience working with the curriculum and children with diverse learning needs one would also expect his/her knowledge base in academic related areas to expand (i.e., reading, writing, language). As seen in the Mather et al. (2001) study, inservice and preservice teachers had differing levels of language form knowledge. However, this study did not consider how differing amounts of experience influenced inservice teachers' knowledge of language form. For these reasons, it would be interesting to compare the 
language knowledge of teachers with no teaching experience (i.e., preservice teachers) to teachers with increasing levels of experience.

Experience gained through working with children in the classroom and experience gained from additional education and/or training may differently influence one's knowledge of language. Teachers bring different types of training experience to the classroom. For example, preservice teachers are typically able to choose elective courses as part of their teacher education programs. Therefore, there will be some differences in the courses teachers took as part of their initial training (i.e., some may have taken a special education course, others may not have). In addition, some teachers have a level of basic training (i.e., Bachelor of Education degree), while others return to university to pursue graduate degrees. One would presume teachers who continue their academic pursuits will also continue to expand their knowledge base of academic related issues, such as their knowledge of language. Comparing the language knowledge of preservice teachers, inservice teachers, and inservice teachers who are also taking graduate level courses at a university would be a second area of interest to explore.

It is the primary responsibility of teachers working in early elementary and middle years classrooms to develop students' oral language, written language, and reading skills. Predominantly, teachers working in Kindergarten to Grade 3 focus on developing students' oral language, reading, and written language skills, while teachers in Grade 4 to Grade 6 expand on this base of knowledge. Although upper elementary and secondary teachers continue to address language and reading skills in junior and senior high, teachers trained to work with older students may have specialist training in content areas that have less of a focus on language and/or reading (e.g., science and math). Therefore, early elementary teachers (Kindergarten to Grade 3) should have more experience with, and potentially a more extensive understanding of, language and literacy development than teachers working in either the middle elementary grades or upper elementary to secondary grades.

Taking this information into account, it was hypothesized:

1. Teachers will have low levels of knowledge in all three language domains, but demonstrate the lowest levels of knowledge in the domain of language form.

2. Teachers with more teaching experience and more specialized training (i.e., university coursework beyond their teacher training program) will perform better on all three subtests.

3. Teachers working in upper elementary and secondary classrooms (Grade 7 to Grade 12) will not perform as well as teachers working in early elementary (Kindergarten to Grade 3 ) and middle elementary classrooms (Grade 4 to Grade 6) on all three language domains.

\section{Method}

\section{Participants}

Participants in this study were 236 teachers $\left(n_{\text {preservice }}=63 ; n_{\text {inservice }}=173\right)$ ranging in age from 21 to 62 years $(M=37.0 . S D=11.2)$. One hundred and ninety-eight participants $(83.9 \%)$ were female and $36(15.3 \%)$ were male; two participants did not report their gender. Participants' total years of teaching experience ranged from 0 to 38 years $(M=11.3, S D=10.5)$. Approximately $27.3 \%$ of the participants were preservice teachers with no teaching experience $(n=63)$, $26.8 \%$ had less than 5 years of teaching experience $(n=62), 22.1 \%$ possessed 5 to 15 years of 
teaching experience $(n=51)$, and $23.8 \%$ had more than 16 years of teaching experience $(n=55)$. Background education varied: 130 participants reported that they had never taken a course in linguistics, while 101 participants reported they had taken at least one course. In contrast, 64 participants reported they had never taken a course in special education, while 121 participants reported they had taken one special education course, and 47 participants reported they had taken two or more courses in special education. At the time of survey, almost one-third of the participants $(n=68)$ were current graduate students.

\section{Measures}

Assessment of Oral Language Knowledge. The Assessment of Oral Language Knowledge scale (AOLK; McIntyre, 2005) was developed to investigate three domains of teachers' knowledge of oral language: form, content, and use. These domains were used as the dependent variables in this study. Although a relatively new scale to the field, the AOLK scale was judged by a panel of language arts experts to demonstrate evidence of content validity (McIntyre, 2005). A complete description of the development and preliminary validation of the AOLK scale is available (see McIntyre, 2005).

The domain of language form consists of 49 dichotomously scored (i.e., correct/incorrect) items. Item topics include identifying morphemes (free and bound), the number of syllables and morphemes, consonant blends, and phonemes in provided words (Moats, 1994, 2000). For example, given a list of words, participants were asked to "circle the free morpheme from which each longer word is constructed" (McIntyre, 2005, p. 183). Possible subscale scores ranged from 0 to 49. Internal consistency (as measured by Cronbach's alpha) of the language form subscale was high ( $\hat{\alpha}=0.91$; McIntyre, 2005).

The domain of language content was represented by 25 items. Item topics include categorizing related words, explaining multiple meaning words, explaining the literal and figurative interpretations for idioms, and explaining multiple meaning sentences (Fromkin, Rodman, Hultin, \& Logan, 1997; Moats, 2000; Parker, 1986). For example, given sentences containing multiple meaning words participants were asked to "identify the multiple meaning word(s), and provide two paraphrases explaining two of the possible meanings of each sentence" (McIntyre, 2005 , p. 185). Seventeen of the 25 items were dichotomously scored (correct/incorrect) and 8 were polytomously scored. Possible scores on this subscale ranged from 0 to 33. Internal consistency of the language content subscale was acceptable ( $\hat{\alpha}=0.78$; McIntyre, 2005).

Ten items examined the domain of language use. Items included examining knowledge of language registers and language functions (Bainbridge \& Malicky, 2000; Halliday, 1973, 1975). For example, given a list of the seven functions of language (Halliday, 1973, 1975), and a series of examples, participants were asked to "identify which one of the seven language functions described above is best represented..." in each example (McIntyre, 2005, p. 187). All 10 items were dichotomously scored (correct/incorrect) and possible scores on this subscale ranged from 0 to 10. Internal consistency for the language use subscale was low ( $\hat{\alpha}=0.59$; McIntyre, 2005). McIntyre (2005) suggested that the lower reliability of the language use subscale may have been due to the smaller number of items representing this subdomain or to the lack of variability in participants' responses to some of the items. These issues will be addressed in the continuing development of this instrument. 
Teacher Characteristics Questionnaire. Information was collected on teacher characteristics' that were hypothesized to influence their knowledge of language. These variables included (a) years of teaching experience, (b) grade level currently teaching, (c) number of linguistic courses taken, and (d) number of special education courses taken. Based on previous research findings (de la Torre Cruz \& Casanova Arias, 2007; Ghaith \& Shaaban, 1999; Ghaith \& Yaghi, 1997; Marso \& Pigge, 1997), years of teaching experience was separated into three groups: (a) beginning teachers (teachers with less than 5 years of experience including preservice teachers); (b) experienced teachers (teachers with 5 to 15 years of experience); and (c) highly experienced teachers (teachers with at least 16 years of experience). Grade level taught was divided into three groups: Kindergarten to Grade 3 (early elementary), Grade 4 to Grade 6 (middle elementary), and Grade 7 to Grade 12 (upper elementary to secondary).

\section{Procedure}

Participants completed the consent form, the AOLK (McIntyre, 2005), and the background information questions and returned all of the documents to the researcher in the envelope provided. In order to ensure anonymity, all participants' names were removed and replaced with a code number as they were received. Any documentation identifying the individual by name and their assigned code number was kept separate from their questionnaire responses. This study was reviewed and approved by the appropriate research ethics board. All participation was voluntary.

\section{Data Analyses}

Descriptive analyses were conducted to examine the characteristics of the teacher sample. Following the standardization of all dependent variables (due to unequal item numbers composing the three subscales), separate one-way multivariate analyses of variance (MANOVAs) were conducted for each of the independent variables. These analyses were used to determine whether any statistically significant differences existed between teachers' knowledge of language form, content, and use according to the different teacher characteristics. Although factorial MANOVA could not be conducted due to missing data and the resulting small number of participants appearing in each cell, MANOVA was utilized since the subscales of the AOLK (McIntyre, 2005) appeared to be related (Tabachnick \& Fiddell, 2007).

\section{Results}

\section{Descriptive Analyses}

Characteristics of participants' raw scores on the three domains are described in Table 1. Standardized scores on the language form subscale were approximately normally distributed and ranged from -2.581 to 2.544 . In comparison, the standardized scores on the language content subscale were negatively skewed with a minimum score of -4.171 and a maximum score of 1.559. This result indicated that while many teachers were able to perform well on this subscale, a few teachers found the language content scale to be very difficult. Most of the teachers found the language use subscale to be easy; however, a few participants did score poorly on this subscale as represented by standardized scores ranging from -3.034 to 0.947 . The language use subscale was the easiest of all subscales for teachers to complete. 
Table 1

Participants' Raw Scores on the AOLK

\begin{tabular}{lllrl}
\hline Subscale & Min. & Max. & Mean & $S D$ \\
\hline Form & 3 & 48 & 25.67 & 8.26 \\
Content & 6 & 33 & 25.65 & 4.65 \\
Use & 4 & 10 & 8.57 & 1.50 \\
\hline
\end{tabular}

Note. Min. indicates minimum raw score; Max. indicates maximum raw score.

Due to the negatively skewed content scores, the language content subscale was re-examined for outlying scores. Two participants were removed from further data analyses following their identification as outlying scores (see Figure 1).

Figure 1

Outliers for language content subscale.

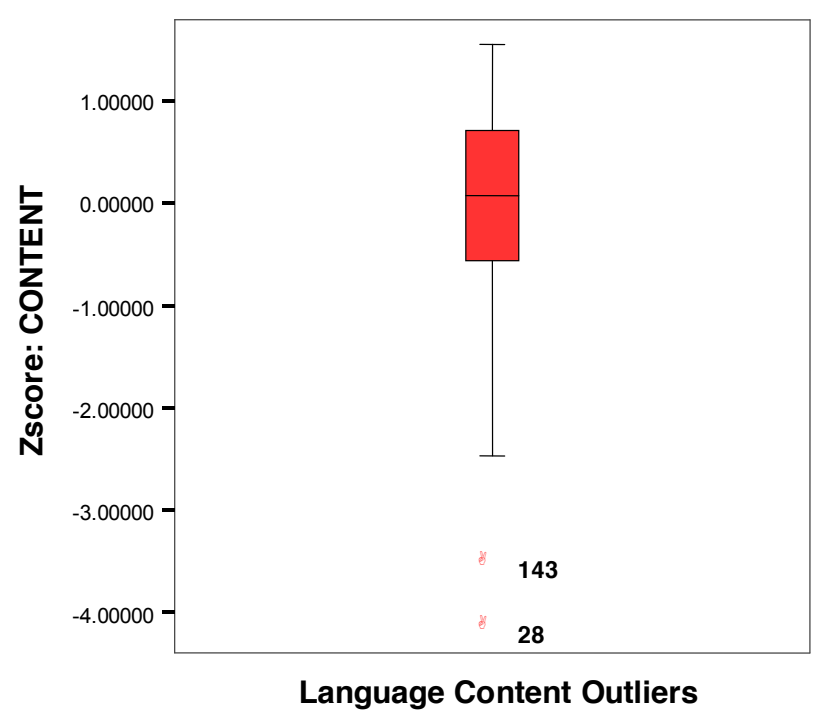

Table 2 presents the number of participants and the standardized mean and standard deviation values for each of the subscales by independent variable. These results suggest that highly experienced teachers (i.e., teachers with 16 or more years of teaching experience) performed better than experienced teachers (i.e., teachers with experience ranging from 5 to 15 years) and beginning teachers (i.e., preservice and teachers with less than 5 years of experience) on the subscales of language form, content, and use. In turn, experienced teachers also appear to have performed better than beginning teachers on the subscales of language form, content, and use. In comparison, secondary (i.e., junior and senior high school teachers, Grade 7 to Grade 12) teachers appear to have had more difficulty with the language form, content, and use subscales than 
Table 2

Standardized AOLK Subscale Scores by Teacher Characteristics

\begin{tabular}{|c|c|c|c|c|c|c|c|c|}
\hline & & \multicolumn{3}{|c|}{ Form } & \multicolumn{2}{|c|}{ Content } & \multicolumn{2}{|c|}{ Use } \\
\hline & & $n$ & $M$ & $S D$ & $M$ & $S D$ & $M$ & $S D$ \\
\hline \multirow{3}{*}{$\begin{array}{l}\text { Years of } \\
\text { experience }\end{array}$} & Beginning & 73 & -0.436 & 0.830 & -0.554 & 0.937 & -0.380 & 0.120 \\
\hline & experienced & 61 & 0.146 & 1.026 & 0.237 & 0.942 & 0.360 & 0.686 \\
\hline & $\begin{array}{l}\text { Highly expe- } \\
\text { rienced }\end{array}$ & 68 & 0.341 & 0.992 & 0.463 & 0.650 & 0.053 & 0.973 \\
\hline \multirow{3}{*}{$\begin{array}{l}\text { Grade level } \\
\text { taught }\end{array}$} & K-3 & 56 & 0.150 & 0.974 & 0.343 & 0.689 & 0.153 & 1.039 \\
\hline & $4-6$ & 27 & 0.156 & 0.895 & 0.365 & 0.653 & 0.136 & 0.744 \\
\hline & $7-12$ & 18 & -0.240 & 0.967 & -0.127 & 1.245 & 0.099 & 0.960 \\
\hline \multirow{3}{*}{$\begin{array}{l}\text { Special Ed } \\
\text { courses }\end{array}$} & 0 & 53 & 0.134 & 0.981 & 0.082 & 1.030 & 0.004 & 1.038 \\
\hline & 1 & 111 & -0.221 & 0.928 & -0.112 & 0.898 & -0.105 & 1.105 \\
\hline & $>1$ & 37 & 0.398 & 1.077 & 0.315 & 0.996 & 0.194 & 0.736 \\
\hline \multirow{2}{*}{$\begin{array}{l}\text { Linguistic } \\
\text { course }\end{array}$} & 0 & 114 & -0.348 & 0.885 & 0.072 & 0.972 & 0.080 & 0.939 \\
\hline & 1 or More & 85 & 0.015 & 1.138 & -0.026 & 0.922 & -0.161 & 1.141 \\
\hline
\end{tabular}

either teachers of middle elementary grades (i.e., Grade 4 to Grade 6) or early elementary grades (i.e., Kindergarten to Grade 3). There did not appear to be a consistent difference in performance between middle elementary and early elementary teachers across the subscales. Although teachers who have taken more than one course in special education appear to have performed better across all three subscales than teachers with one or no courses in special education, teachers with no formal special education classes performed better than those teachers who had taken one course. Lastly, while teachers with one or more linguistics courses performed better on the subscale of language form, teachers with no formal coursework in linguistics performed better on the subscales of language content and use.

\section{MANOVA Tests of Statistical Significance}

Due to the smaller sample sizes found in some of the cells, Pillai's criterion was chosen as the criterion to evaluate multivariate significance as it is said to be more robust to violations of homogeneity of variance (Olson, 1979). Separate one way MANOVAs were conducted for the four independent variables - years of teaching experience, grade level currently teaching, number of special education courses taken, and number of linguistic courses taken. Results demonstrated no statistically significant differences in any of the language subscales for grade level currently teaching or number of linguistics courses taken. 
In contrast, the MANOVA for years of teaching experience was significant, $F(6,394)=$ $11.008, p<0.001, \eta^{2}=0.143$. Univariate ANOVAs identified statistically significant differences for language form, content, and use. Multiple comparisons using the Tukey procedure also identified two statistically significant comparisons for each of the dependent variables (see Table 3). For each language domain, highly experienced and experienced teachers scored higher on the subscales than beginning teachers. No statistically significant differences were identified between highly experienced and experienced teachers.

The MANOVA for number of special education courses taken was statistically significant, $F(6,394)=2.369, p=0.029, \eta^{2}=0.013$. The univariate ANOVA identified a statistically significant difference for language form. Multiple comparisons using the Tukey procedure identified one statistically significant comparison: Teachers who took more than one special education course performed significantly better than teachers who took one special education course (see Table 3).

Table 3

Statistically Significant Univariate ANOVA and Multiple Comparison Results

\begin{tabular}{|c|c|c|c|c|c|}
\hline DV & & $F$ value & df & $\eta^{2}$ & Multiple Comparisons \\
\hline Form & $\begin{array}{l}\text { Beginner } \\
\text { Experienced } \\
\text { Highly Experienced }\end{array}$ & $12.538^{*}$ & 2,198 & 0.112 & $\mathrm{HE}$ and $\mathrm{E}>\mathrm{Beg}$ \\
\hline Content & $\begin{array}{l}\text { Beginner } \\
\text { Experienced } \\
\text { Highly Experienced }\end{array}$ & $27.341^{*}$ & 2,198 & 0.216 & $\mathrm{HE}$ and $\mathrm{E}>\mathrm{Beg}$ \\
\hline Use & $\begin{array}{l}\text { Beginner } \\
\text { Experienced } \\
\text { Highly Experienced }\end{array}$ & $9.365^{*}$ & 2,198 & 0.086 & $\mathrm{HE}$ and $\mathrm{E}>\mathrm{Beg}$ \\
\hline Form & $\begin{array}{l}0 \text { Special Ed. Courses } \\
1 \text { Special Ed. Course } \\
2+\text { Special Ed. Courses }\end{array}$ & $6.505^{*}$ & 2,198 & 0.062 & 2+ Special Ed. > 1 \\
\hline Content & $\begin{array}{l}0 \text { Special Ed. Courses } \\
1 \text { Special Ed. Course } \\
2+\text { Special Ed. Courses }\end{array}$ & 2.944 & 2,198 & 0.029 & \\
\hline Use & $\begin{array}{l}0 \text { Special Ed. Course } \\
1 \text { Special Ed. Course } \\
2+\text { Special Ed. Courses }\end{array}$ & 1.183 & 2,198 & 0.012 & \\
\hline
\end{tabular}

Note. ${ }^{*}$ is significant at a .05 alpha level; HE refers to Highly Experienced teachers; E refers to Experienced teachers; Beg refers to Beginning teachers; 2+ Special Ed. refers to teachers who took more than 1 Special Education course; 1 refers to teachers who took one Special Education course. 


\section{Discussion}

The hypothesis that teachers would have low levels of knowledge in all three language domains, but demonstrate the lowest levels of knowledge in the domain of language form was partially supported. Teachers demonstrated low levels of knowledge on the subscales of language form and language content and higher levels of knowledge on the subscale of language use. On average, teachers had lower levels of language knowledge in the domain of language form than the domain of language content. A possible explanation for teachers' lower levels of language knowledge in the domain of language form could be related to the courses and/or information offered in teacher education programs and continuing education opportunities. Teachers may not have been exposed to coursework specifically relating to language form (i.e., phonemes, morphemes) in their teacher education programs or in continuing education opportunities offered in their school divisions. However, language arts coursework in teacher training programs and in continuing education opportunities typically address topics relating to language content (i.e., vocabulary development relating to multiple meaning words, idioms, etc.). Therefore, teachers may have had more exposure to courses and inservices relating to the domain of language content than the domain of language form.

It was also found that teachers who had not completed a special education course during their training performed better than teachers who had completed one course in special education. This finding may be more related to teaching experience than teachers' understanding of the content presented in special education courses. However, the teacher sample in this study was not large enough to examine why individuals who had not taken any special education coursework in their teacher education programs may have performed better than individuals who had taken special education coursework (i.e., were not able to examine potential interactions between variables). In addition, teachers' higher levels of knowledge on the subscale of la nguage use may not indicate that teachers had a better understanding of the domain of language use. This finding may instead be related to subscale items. That is, the subscale of language use contained fewer items than the other subscales, and teachers may have found these items relatively easy to complete. A lower number of items and subscale items that were less difficult than those in other subscales likely contributed to the lower reliability found for the subscale of language use. This could explain why teachers were found to have higher levels of language knowledge in the domain of language use.

Second, it was hypothesized that teachers with more teaching experience and more specialized training (i.e., specialized coursework in their teacher education programs, university coursework beyond their teacher training program) would perform better on all three subtests. This hypothesis was supported. Preservice teachers across all three subscales did not perform as well as teachers with any level of experience, which was anticipated since one expects a person's knowledge base to expand as more work experience is gained. The variable measuring teachers' specialized training - type of teacher training - was also statistically significant for the subscales of language form and language content. That is, inservice teachers and inservice teachers who were also taking graduate level courses at a university performed better on the subscales of language form and language content than preservice teachers. Although the difference between

preservice teachers and both groups of inservice teachers was significant on the language use subscale, these findings were not practically significant since on average there was only a one point difference between the groups. 
Third, it was hypothesized that teachers working in upper elementary and secondary schools (Grade 7 to Grade 12) would not perform as well as teachers working in early elementary (Kindergarten to Grade 3) and middle elementary years (Grade 4 to Grade 6) classrooms on all three language domains. Preservice teachers, who had no teaching experience in their own classrooms, were removed from the analysis of this variable. The variable grade level currently teaching was not statistically significant for the domains of language form, content, or use. This was due to the fact that there was insufficient power, likely the result of a reduced sample size ( $n$ $=102$ ), to run a MANOVA for this variable. In order to better understand whether this variable does influence teachers' knowledge of language, a future study looking at the grade level teachers reported currently teaching, in relation to teachers' knowledge of language, should be completed with a larger sample of teachers (i.e., $n>200$ ).

No gender differences were hypothesized. However, females were found to have outperformed males on both the language form and language content subscales. No significant gender difference was found for language use. These findings may be a product of more females typically teaching in the elementary grades or because there were relatively few males in the sample. In a predominantly female profession, such as education, it is often difficult to obtain equal size samples of males and females. Future studies should make a concerted effort to obtain a larger male sample. In regard to the subscale of language use, as previously discussed, these results may be related to the small number of items comprising the subscale and/or the difficulty level of the questions. These factors likely contributed to the lower reliability of the language use subscale.

In summary, although both preservice and inservice teachers had low levels of language knowledge, experienced teachers, inservice teachers, and inservice teachers taking graduate level courses at a university tended to perform better than preservice teachers with no teaching experience on all three subscales. These findings have implications for teacher training programs and for professionals providing support services to classroom teachers.

\section{Practical Implications}

Understanding the gaps that may exist in teachers' knowledge of language form, content, and use would be beneficial for professionals providing support to classroom teachers (e.g., SLPs). SLPs typically provide support to classroom teachers to meet the needs of students with language-based difficulties (e.g., literacy difficulties). First, SLPs would get an idea of the knowledge of oral language teachers bring to their collaborative partnerships. This information would assist the SLP in determining the type and amount of support individual teachers need in order to assist in (a) the identification of students at risk for speech and language problems and (b) the implementation of programming for identified students in their classroom. For example, if a student in the middle elementary years (Grade 4 to Grade 6) is demonstrating receptive and expressive vocabulary deficits, then curriculum adaptations may need to be made. The SLP can work with the classroom teacher and provide suggestions for addressing these difficulties. However, if classroom teachers need to expand their understanding of language content (semantics) then they may need additional support from the SLP. These teachers may need support in improving their understanding of these aspects of language before they can effectively implement the SLP's suggestions in the classroom. SLPs can also use information about teachers' knowledge of language to guide the content of any professional development sessions they provide to 
the teachers with whom they work. For example, upper elementary teachers could complete the assessment tool. Any aspects of language with which these teachers had difficulty could be directly addressed in continuing education opportunities provided to this group. Understanding the language knowledge base teachers bring to their collaborative partnerships can only assist SLPs in tailoring information sessions and inservice opportunities to address school staff members' areas of need.

Second, understanding the level of teachers' oral language knowledge would provide professionals responsible for designing and implementing courses in teacher education programs information supporting the inclusion of oral language content in required coursework. Strengthening teacher education courses in the area of oral language would increase the opportunities for preservice teachers entering the field to improve their knowledge of this area. Increasing preservice and inservice teachers' opportunities to learn more about oral language could only benefit students experiencing language and/or literacy difficulties in our classrooms.

\section{Future Research}

In order for teachers, administrators, and other school-based personnel to further their understanding of teachers' knowledge of language more research needs to be conducted. For example, future research should involve the addition of items referenced to the domain of language use in order to increase the internal consistency of the domain scores. The Assessment of Oral Language Knowledge (McIntyre, 2005) instrument then needs to be empirically assessed to ensure that the revisions yield scores that can be validly and reliably interpreted. Second, a larger sample of teachers should be targeted to investigate whether the grade level in which a teacher is currently teaching is significantly related to their knowledge of language form, content, and use. A larger sample of teachers (i.e., $n>250$ ) would allow additional types of analyses to be conducted in order to better understand the relationship of various teacher characteristics to teachers' oral language knowledge (i.e., factorial ANOVAs, MANOVAs to analyze interactions among dependent variables). For example, if there was a large enough sample to examine the interaction between coursework and teaching experience, then the reason why individuals who had not taken any special education coursework in their teacher training performed better than individuals who had taken special education coursework could possibly have been explained (i.e., did teachers with no coursework in special education have more teaching experience?).

Classroom teachers are typically the professionals primarily responsible for addressing the diverse educational needs of students experiencing language and/or literacy difficulties. Learning more about the oral language knowledge of teachers, and the teacher characteristics that may influence this knowledge, can help to shed more light on factors that may be contributing to, or hindering, the development of students' language and literacy skills.

\section{References}

Adams, C., \& Bishop, D. V. M. (1989). Conversational characteristics of children with semanticpragmatic disorder. I: Exchange structure, turntaking, repairs and cohesion. British Journal of Disorders of Communication, 24(3), 211-239.

Adams, M. J. (1990). Beginning to read: Thinking and learning about print. Cambridge, MA: MIT Press. 
American Speech-Language-Hearing Association. (2001). Roles and responsibilities of speech-language pathologists with respect to reading and writing in children and adolescents (position statement, executive summary of guidelines, technical report). ASHA Supplement, 21, 17-28. Rockville, MD: Author.

Bainbridge, J., \& Malicky, G. (2000). Constructing meaning: Balancing elementary language arts (2nd ed). Toronto, ON: Harcourt Canada.

Catts, H. W. (1996). Defining dyslexia as a developmental language disorder: An expanded view. Topics in Language Disorders, 16(2), 14-29.

Catts, H. W., Adlof, S. M., \& Weismer, S. E. (2006). Language deficits in poor comprehenders: A case for the simple view of reading. Journal of Speech, Language, and Hearing Research, 49(2), 278293.

Catts, H. W., Fey, M. E., Zhang, X., \& Tomblin, J. B. (1999). Language basis of reading and reading disabilities: Evidence from a longitudinal investigation. Scientific Studies of Reading, 3, 331-361.

Catts, H. W., \& Kamhi, A. G. (1999). Language and reading disabilities. Boston: Allyn \& Bacon.

de la Torre Cruz, M. J., \& Casanova Arias, P. F. (2007). Comparative analysis of expectancies of efficacy in in-service and prospective teachers. Teaching and Teacher Education, 23(5), 641-652.

Feagans, L., \& Short, E. J . (1984). Developmental differences in the comprehension and production of narratives by reading-disabled and normally achieving children. Child Development, 55, 17271736.

Fromkin, V., Rodman, R., Hultin, N., \& Logan, H. (1997). An introduction to language (1st Canadian ed.). Toronto, ON: Harcourt Brace.

Ghaith, G., \& Shaaban, K. (1999). The relationship between perceptions of teaching concerns, teacher efficacy, and selected teacher characteristics. Teaching and Teacher Education, 15(5), 487-496.

Ghaith, G., \& Yaghi, H. (1997). Relationships among experience, teacher efficacy, and attitudes toward the implementation of instructional innovation. Teaching and Teacher Education, 13(4), 451-458.

Halliday, M. A. K. (1973). Explorations in the functions of language. London: Edward Arnold.

Halliday, M. A. K. (1975). Learning how to mean: Explorations in the development of language. New York: Elsevier North-Holland.

Hogan, T. P., Catts, H. W., \& Little, T. D. (2005). The relationship between phonological awareness and reading: Implications for the assessment of phonological awareness. Language, Speech, and Hearing Services In Schools, 36(4), 285-293.

Klecan-Aker, J. S., \& Swank, P. R. (1987). The narrative styles of normal first and third grade children. Language and Speech, 30(3), 251-262.

Klecan-Aker, J. S., \& Swank, P. R. (1988). A comparison of the use of language functions by normal and language-disordered children. Journal of Childhood Communication Disorders, 11(2), 263-274.

Lerner, J. (1997). Learning disabilities: Theories, diagnosis, and teaching strategies. Boston: Houghton Mifflin.

Marso, R. N., \& Pigge, F. L. (1997). A longitudinal study of persisting and nonpersisting teachers' academic and personal characteristics. The Journal of Experimental Education, 65(3), 243-254.

Mather, N., Bos, C., \& Babur, N. (2001). Perceptions and knowledge of preservice and inservice teachers about early literacy instruction. Journal of Learning Disabilities, 34, 472-482.

McCutchen, D., Abbott, R. D., Green, L. B., Beretvas, S. N., Cox, S., Potter, N. S., et al. (2002). Beginning literacy: Links among teacher knowledge, teacher practice, and student learning. Journal of Learning Disabilities, 35, 69-86.

McIntyre, L. J. (2005). Investigating teachers' knowledge of oral language. Unpublished doctoral dissertation, University of Alberta, Edmonton, Alberta, Canada.

Moats, L. C. (1994). The missing foundation in teacher education: Knowledge of the structure of spoken and written language. Annals of Dyslexia, 44, 88-102.

Moats, L. C. (2000). Speech to print: Language essentials for teachers. Baltimore: Paul H. Brookes Publishing. 
Moats, L. C., \& Lyon, G. R. (1996). Wanted: Teachers with knowledge of language. Topics in Language Disorders, 16, 73-81.

Olson, C. L. (1979). Practical considerations in choosing a MANOVA test statistic: A rejoinder to Stevens. Psychological Bulletin, 86, 1350-1352.

Parker, F. (1986). Linguistics for non-linguists. Austin, TX: Pro-Ed.

Rath, L. K. (1994). The phonemic awareness of reading teachers: Examining aspects of knowledge. Unpublished doctoral dissertation, Harvard University, Cambridge, MA.

Roth, F. P., Speece, D. L., \& Cooper, D. H. (2002). A longitudinal analysis of the connection between oral language and early reading. The Journal of Educational Research, 95(5), 259-272.

Roth, F. P., \& Spekman, N. J. (1991). Higher-order language processes and reading disabilities. In A. G. Kamhi \& H. W. Catts (Eds.), Reading disabilities: A developmental language perspective (pp. 159-197). Needham Heights, MA: Allyn \& Bacon.

Snow, C. E., \& Burns, M. S. (Eds.). (1998). Preventing reading difficulties in young children. Washington, DC: National Academy Press.

Stanovich, K. E. (1988). Explaining the differences between the dyslexic and the garden-variety poor reader: The phonological-core variable-difference model. Journal of Learning Disabilities, 21, 590-604, 612.

Stanovich, K. E., \& Siegel, L. S. (1994). Phenotypic performance profile of children with reading disabilities: A regression-based test of the phonological-core variable-difference model. Journal of Educational Psychology, 86, 24-53.

Stothard, S. E., Snowling, M. J., Bishop, D. V. M., Chipchase, B. B., \& Kaplan, C. A. (1998). Languageimpaired preschoolers: A follow-up into adolescence. Journal of Speech, Language, and Hearing Research, 41, 407-418.

Swan, D., \& Goswami, U. (1997). Picture naming deficits in developmental dyslexia: The phonological representation hypothesis. Brain and Language, 56, 334-353.

Tabachnick, B. G., \& Fiddell, L. S. (2007). Using multivariate statistics (5th ed.). Boston: Allyn \& Bacon.

Torgesen, J. K., Wagner, R. K., \& Rashotte, C. A. (1994). Longitudinal studies of phonological processing and reading. Journal of Learning Disabilities, 27, 276-286.

\section{Authors' Note}

Correspondence concerning this article should be addressed to Laureen J. McIntyre, Assistant Professor and Director of the Special Education Certificate Program, Department of Educational Psychology and Special Education, University of Saskatchewan, 28 Campus Drive Saskatoon, SK S7N 0X1. E-mail: laureen.mcintyre@usask.ca 